\title{
Legal Study on Non-Commercial Risk Investment in Indonesia
}

\author{
Feibe Engeline Pijoh* \\ Law Studies Program \\ Faculty of Social Sciences, \\ Universitas Negeri Manado \\ Manado, Indonesia \\ feibepijoh@gmail.com
}

\author{
Isle Junita Melo \\ Law Studies Program \\ Faculty of Social Sciences, \\ Universitas Negeri Manado \\ Manado, Indonesia \\ isyemelo@unima.ac.id
}

\begin{abstract}
The purpose of this study is to find out about the legal guarantees given by the Government of Indonesia of non-commercial risk investment. Therefore, investment is an important pillar in the economic growth of a country due to the country's economy needs to grow sustainably requires continuous capital. In Indonesian income per capita is very low, the government is trying to attract investors to invest their capital by managing a variety of available resources, by providing a clear legal regulated in Law No. 25/2007 on investment, and various other supporting regulations, which protects the interests of investors. The problem occurs when a country experiences a political crisis, where this can lead to non-commercial risks greatly affect investors, in this study formulate the problem how does the legal guarantee from the government if there is a non-commercial risk in terms of investment to investors. To answer this problem, a normative legal approach is used will analyze the legal material by referring to legal norms in the applicable laws and regulations. The results show that Article 7 of Law No. 25/2007 provides protection and legal certainty for investors, if there is a non-commercial risk associated with political turmoil, the government will not nationalize and take over assets to investors due Indonesia as a developing country is still dire need foreign and domestic investors to invest their capital in our country to grow national economic.
\end{abstract}

Keywords: Risk, non-Commercial, Investment

\section{INTRODUCTION}

The presence of foreign investors in a country has quite extensive benefits due to absorbing labor in the recipient country of capital, adds to the country's foreign exchange due to many foreign investors are oriented to export-import; also increase state income from the tax sector; and the transfer of technology and knowledge transfer brought by investors. By reviewing this point of view, investors are very instrumental in the economic development of a country. For this reason, various improvements have been made by the government, aimed to create a conducive climate for investment in Indonesia, by the issuance of Law No. 25/2007 on Investment, the existence of this act will be able to guarantee legal certainty, comfort, and security for investors.

The investors in investing their capital expect there is a result or profit in running their business, hope the capital invested remains safe, in the sense of legal protection. If an investor experience of losses in running and managing his business, then for investors this is a business risk should be borne, as stated by reference [1], as follows: "An individual who invests funds in any type of security or business undertaking, or who even holds his assets in cash form, assumes the possibility of loss, or conversely, has an opportunity to gain. Four major risks or uncertainties for investors might be distinguished as follows: 1 . business risk; 2 . interest rate risk; 3 . marked risk; 4. purchasing power risk. To select an investment, an investor had to decide the degree of business risk he wishes to assume. He has a choice."

For the investors before deciding to invest their capital, firstly conducted a feasibility study of the business prospects he would run. If an investor will invest their capital, the investor should sign a letter of intent accompanied by a preferability study, include legislation relating to the investment to be made. Issues will arise if in conducting their business, investors experience noncommercial risk. This research formulates the problem of the guarantee of legal certainty from the government event of a non-commercial risk to investors.

This research is expected to be useful both theoretically and practically. Theoretical benefits in the sense of being able to answer the problems faced, this research may be useful as a contribution to investors and the public regarding Investment in Indonesia, especially relating to the assurance of legal certainty of noncommercial risk.

\section{RESEARCH METHODS}

This research is normative legal research which is one type of legal research. The normative legal approach is used to analyze primary legal materials, according to the Law No. 25 of 2007 concerning Investment, and Secondary legal materials, various liter that support this writing, as well as tertiary legal materials in the form of law dictionaries and Indonesian dictionaries. This approach is conducted by referring to the legal norms outlined in the legislation and court decisions. The process of gathering legal material is conducted by the procedure of identifying and inventorying positive law as a preliminary activity, analyzed based on descriptive normative analysis, by describing and explaining in detail all related to the issues raised. 


\section{RESULTS AND DISCUSSION}

\section{Concept of Welfare State}

The concept of the welfare state is used due to the concept of welfare refers to social welfare development which is a series of planned and institutionalized activities aimed at improving the standards and quality of human life [2]. The concept of welfare in the context of national development can be defined as all policies and programs conducted by the government, business world, and civil society to overcome social problems and meet human needs with economic improvement.

In this case, the concept of the Welfare State focuses on social welfare and economic development, which reference [3] calls antithetical notions. Economic development is concerned with the growth of capital accumulation and economic benefits, while social welfare is related to altruism, social rights, and asset redistribution. Economic development is conducted by increasing wealth and improving quality and living standards.

Based on the concept of the Welfare State through economic development, to realize and improve prosperity, acceleration, improvement, and economic development should be done through national economic development in line with the state constitution which has mandated national economic development should be based on democratic principles which create the realization of the sovereignty Indonesian economy. Economic development based on democratic principles is a manifestation of people's economy as stipulated in Article 33 of the 1945 Constitution which is the normative, philosophical basis of a people's economic system [4]

\section{The Concept of Investment and Capital Investment}

Regarding investment, it has a broader understanding due to cover both direct investment and indirect investment, whereas it has more connotation to direct investment. In general, the investment can be interpreted as an activity conducted both persons and legal entities, an effort to increase and/or maintain its capital value, whether in the form of cash, equipment, immovable assets, rights for intellectual property, as well as expertise.

According to the economic point which views the investment as one factor of production, the investment can be interpreted as:

1. an action for buying shares, bonds, or other investments,

2. an act of buying capital goods,

3. utilization of funds available for production for future income [5].

According to the Investment Law No. 25 of 2007 , Article 1 paragraph [6], investment is defined as all forms of investment activities, both by domestic investors and foreign investors to do business in the territory of the Republic of Indonesia.

\section{Concept of Non-commercial Risk}

If it is examined based on the word non-commercial, it means something that is done by a person or legal entity to seek profit. However, the non-commercial risk referred to this research is a state of the country which at the time was in a state of political turmoil, it also affected the state of the country's economy to the impact of a noncommercial risk for investors.

This risk is referred to as political risk, due to closely related to the political conditions of a country. This Political Risk is also related to the possibility of changes in statutory provisions which result in a decrease in the estimated income of an investment or even a total loss of the invested capital. For companies operating abroad, the economic and political stability of the country concerned will need to be considered to avoid a high country's risk. Likewise, the current situation of all countries has temporarily collapsed in the economy due to the COVID19 which has plagued almost all countries, which has resulted in the economy of each country disturbed. This is categorized as a non-commercial risk.

\section{Investment Guarantee Law for Investors}

The purpose of investment or investment only be achieved if the supporting factors hinder the investment climate can be overcome through:

1. Improved coordination between central and regional government agencies,

2. Creation of an efficient bureaucracy for legal certainty in the field of investment,

3. Competitive economic costs; and

4. A conducive business climate in the field of employment and business security.

Improvements in various factors, it is hoped investment has an important role in improving the economy and employment growth. Governments around the world are currently competing to create a better business climate to support investment activities. Whether we realize it or not, foreign and domestic investment is very beneficial for economic growth. High economic growth can be supported by several factors, including a) support of trade and investment deregulation policies; b) a conducive business climate to accelerate the pace of investment increase, and c) also the existence of international confidence in the domestic economic actors to conduct various forms of old joint venture work.

The world economy is characterized by increasingly fierce international competition investment policies should be encouraged to create national economic competitiveness to encourage the integration of the Indonesian economy into the global economy. The Investment Law should be able to accommodate competition. There are three qualities created by the Investment Law, to encourage foreign investment as follows: 1) stability; 2) predictability; 3) fairness. The first and second points are prerequisites for the economic system to function. Predictability requires the law to bring certainty. Investors will be interested in a country if he believes the law will protect investments made.

Legal certainty is as important as economic opportunity and political stability. Second, it should be able to create the stability that is balanced or accommodates competing interests in society. In this case, the Investment Law accommodates the interests of foreign capital and protect local entrepreneurs or small businesses. Third, fairness or equality such as the equality of all people or parties before the law, equal treatment of all people and the existence of a standard pattern of government policies by many experts emphasized as a prerequisite for the functioning of market mechanisms and 
preventing excessive bureaucratic actions. To realize a legal system supports the investment climate, clear rules are needed ranging from permits for business to the costs that should be incurred for the operation of the company. The key to achieving this condition is the rule of law enforcement.

Another thing often a concern for potential foreign investors is the issue of legal guarantees from recipient countries, especially those relating to non-commercial risk. It is rather difficult to find, even in countries whose industries are quite advanced, free from political risks. However, in developing countries where the government system is still unstable, the possibility of political risk is indeed quite high. When viewed in terms of security and business convenience it might be safer for investors to invest in developed countries because in developed countries, all the rules are arranged in an orderly manner only the expected level of profit may not be too much, due to the production costs are quite high, competition between similar companies is quite tight.

To expand the business, one option is to invest in developing countries, because besides production costs are not too expensive, the production market is still open, and competition is not too tight. It's just the political risks to be faced are quite high. The political risk (political risk) contains at least four things as stated by reference [7] as follows:

1. Discontinuity, such as the existence of drastic changes in the business environment,

2. Uncertainty (uncertainty), such as the existence of changes that are very difficult to predict and / or, anticipated beforehand,

3. Political forces mean changes are caused or driven by political forces,

4. Impact in the business sector (business impact), meaning a change in political policy results in losses and / or reductions or other objectives of the company. Investors need to note the risks will be faced. It needs to be emphasized what is a non-commercial risk as to the existence of action from the state or the existence of an event related to social upheaval in a country which has direct and indirect consequences on foreign companies. One form of non-commercial risk is expropriation or nationalization of foreign companies. The feared risk is not a business risk, but non-commercial risk. Business risks faced by investors are not uncommon, meaning that in every business activity to be conducted should be risks, but for foreign investors who are generally multinational companies, have sufficient human resources, adequate technology, strong capital and have access to financial institutions, both national and international, by using professional staff, a business can be calculated accurately. The level of business risk will be faced can be minimized as small as possible.

Regarding non-commercial risks, for the Indonesian government, namely the takeover or nationalization of foreign companies will not conduct, except by law. The spirit of the nationalization of foreign companies has also occurred in Indonesia. This happened when Indonesia was only a few years independent, then there was a kind of thought that the presence of foreign companies was an obstacle to the realization of sovereignty in the economic field. But there are other thoughts, that the presence of foreign investors still needed considering indigenous entrepreneurs and skilled workers owned by the Government of Indonesia are inadequate [8]. Finally, in 1958, the Government issued Law No. 86 of 1958 concerning the Nationalization of Dutch Companies. In considering the issuance of the law it was stated: "The nationalization of the Dutch-owned companies is intended to provide maximum benefits to the people of Indonesia and also to strengthen national security and defense". Related to this nationalization, it is explicitly stated in Article 7 paragraph (1) of the Capital Market Law No. 25/2007.

It is forced to do, then the investor will be given compensation in the amount determined based on market prices. If there is no agreement regarding the intended compensation, then investment dispute resolution will be taken to the arbitration institution. From this point of view, for non-commercial risks, for example nationalizing foreign companies, providing guarantees is, if forced to do, then compensation will be given. Other risks that occurred in non-commercial risk are the declining value of the local currency against foreign currencies, social unrest and civil war. For this type of risk, insurance companies usually do not want to guarantee. This noncommercial risk guarantee can be borne solely by the host country unilaterally, through bilateral agreements on investment guarantees and multilateral agreements [9].

To further enhance the confidence of foreign investors to invest in Indonesia, the Indonesian Government made bilateral agreements with various countries of origin of investors. This investment agreement creates several principles that are generally applicable to international relations. The principles referred to include: First, the principle of a national treatment clause, meaning each party will provide the same treatment to the citizens of the parties as granted by the parties to their citizens. Second, the principle of a most favored nation clause, citizens of the parties will get fair and equitable treatment in terms of foreign investment. Citizens of the parties will not get less treatment compared to the treatment given to citizens of other parties [10].

Observing the presence of foreign investors in a country, especially in developing countries, is quite important as a driver of the economy, to eliminate the doubts of foreign investors in investing given that noncommercial risk is very likely to occur, the World Bank has again made a convention, which is related to noncommercial risk or often also referred to as political risk (political risk).

This convention is known as The Convention Establishing the Multilateral Investment Guarantee (MIGA). This convention was held in Seoul-South Korea in 1985, the MIGA convention is often referred to the 1985 Seoul Convention. MIGA is a World Bank Group based in Washington DC.

The State of Indonesia itself has ratified this convention based on Presidential Decree Number 31 of 1986 [11]. The background of the holding of this convention outlined in the Preamble was stated among others the Multilateral Investment Guarantee Agency could play an important role to encourage investment foreign investment through investment guarantee programs both regional and national as well as noncommercial risk guarantee programs that may be faced by investors. 
The purpose and objective of the establishment of MIGA are to encourage investment flows among member countries, and in particular for developing country members. To fulfill the intended purpose, MIGA has the duty to:

1. Providing guarantees to investors, which includes insurance cooperation as well as by reinsurance, preventing non-commercial risks relating to an investment in a member country originating from other member countries;

2. Conducting activities or activities in the form of promotions to increase the flow of investment among members of developing countries.

In this context, the level of implementation should be addressed by the government, to convince potential investors to invest in this country is a legal guarantee.

\section{CONCLUSION}

1. Legal certainty guaranteed by the government to investors in the event of non-commercial risk is based on Article 7 paragraph (1) of Law No. 25 of 2007, expropriation or nationalization of foreign companies will not be conducted, except by law. If this is forced by the government, then the investor will be given compensation in the amount determined based on market prices based on Article 7 paragraph (2). If there is a compensation agreement, compensation will be taken through legal settlement through Arbitration.

2. Foreign investors consider legal certainty and business certainty in Indonesia to be weak, because social costs are too high, and the licensing bureaucracy is too complicated. It is recommended to the government to facilitate licensing services. Even though Law No. 25 of 2007 concerning investment but implementation in the field is weak. This research can provide input to the government in overcoming investment problems and would be useful for the world of education as a material for the study of economic law in particular.

\section{ACKNOWLEDGMENT}

The author would like to the Dean of Faculty of Social Science, Manado State University in supporting the publication of this article.

\section{REFERENCES}

[1] R. E. Badger, H. G. Guthmann, and H. W. Torgerson, Investment Principles and Practices. JSTOR, 1969.

[2] E. Suharto, 'Negara Kesejahteraan dan
Reinventing Depsos', in Makalah disampaikan pada Seminar yang bertema "Mengkaji Ulang Relevansi Welfare State dan Terobosan melalui Desentralisasi-Otonomi di Indonesia" dilaksanakan di Wisma MMUGM, Yogyakarta, 2006.

[3] J. Midgley, 'Growth, redistribution, and welfare: Toward social investment', Soc. Serv. Rev., vol. 73, no. 1, pp. 3-21, 1999.

[4] P. M. Marzuki, 'Penelitian Hukum, Jakarta: Kencana Prenada Media Group, cetakan keenam, 2005'. Hlm.

[5] P. Anoraga, 'Multinasional dan Penanaman Modal Asing', Penerbit Pustaka Jaya, Jakarta, 1995.

[6] D. K. Harjono, 'Hukum Penanaman Modal: Tinjauan Terhadap Pemberlakuan UndangUndang No. 25 Tahun 2007 tentang Penanaman Modal'. Pusat Pengembangan Hukum dan Bisnis Indonesia, 2012.

[7] A. F. E. Erawati, Meniningkatkan investasi asing di negara-negara berkembang: kajian terhadap fungsi dan peran dari the multilateral investment guarantee agency. Pusat Studi Hukum, Universitas Katolik Parahyangan, 1989.

[8] B. Kanumoyoso, Nasionalisasi perusahaan Belanda di Indonesia: menguatnya peran ekonomi negara. Pustaka Sinar Harapan, 2001.

[9] D. S. Suraputra, 'Penanaman Modal Asing dan Resiko Investasi Nonkomersial', in Mochtar Kusumaatmadja Pendidik \& Negarawan. Kumpulan Karya Tulis Menghormati 70 tahun Mochtar Kusumaarmadja, D. Mieke Komar, Ed. Bandung: Alumni, 1999, p. 137.

[10] T. T. Longdong, 'Asas Ketertiban Umum dan Konvensi New York 1958', Bandung PT. Citra Aditya Bakti, 1998.

[11] D. S. Suraputra, 'ICSID dan MIGA: Lembaga Internasional untuk Meningkatkan Arus Penanaman Modal. Dalam Tim Pakar Hukum Depkeh dan HAM RI. Gagasan dan Pemikiran tentang Pembaharuan Hukum Nasiona', Jakarta, 2003. 